\title{
Ecological assessment of two sandy beaches along the Kerala coast, south west coast of India: perspective to pollution.
}

\author{
V Anu Pavithran* and S Bijoy Nandan \\ Department of Marine Biology, Microbiology and Biochemistry, School of Marine Sciences, Cochin University of Science and Technology, India
}

Submission: October 20, 2016; Published: November 30, 2016

*Corresponding author: V Anu Pavithran, Department of Marine Biology, Microbiology and Biochemistry, School of Marine Sciences, Cochin University of Science and Technology, Kochi - 682 016, Kerala, India, Email: anupavithran@gmail.com

\begin{abstract}
The distinct nature of the two shores (Fort Cochin and Dharmadam) of south west coast of India has the potential to evaluate the ecological function and processes. This study observed two different sandy beaches; Fort Cochin and Dharmadam and examined the faunal community structure and anthropological influences. From the entire study, it was uncovered that the shorelines chosen showed disparity in their shoreline profiles and faunal composition. Anthropological invasions and natural processes lead Fort Cochin beach to the threat of obliteration. The Dharmadam beach retained a pristine appearance; however, the temporal evaluation of beach fauna and biotic indices confirmed the occurrence of disturbed community. Impacts of anthropological activities were disclosed in the study and for which various statistical tools and biotic index like AMBI (AZTI's Marine Biotic Index) were applied so that the ecological status of the system could be explored.

AMBI being a biotic index, which derives ecological quality status based on diverse soft bottom macro-fauna as indicators, revealed the proliferation of opportunistic species or $r$ selected species in both beaches, which has an adverse influence on the ecosystem. The application of Caswell neutral model (It is a comparison of Shannon Wiener diversity ( $\mathrm{H}^{\prime}$ ) with expected diversity) also revealed that the predicted diversity value being larger than that of actual diversity in certain seasons, indicating the dominance of organisms there. Both the statistical tools pointed out that the beaches are in the trail of destruction and disturbances, except in some selected stations. An impulsive conservation program should be necessitated to upkeep those pristine beach ecosystems.
\end{abstract}

Keywords: Sandy Beaches; Ecological Comparison; Morphology; Macrofauna; Human impacts

Abbreviations: AMBI: AZTI's Marine Biotic Index; HTM: High Tide Mark; LTM: Low Tide Mark; TDS : Total Dissolved Solids; APHA: American Public Health Association; ANOSIM: Analysis of Similarity; MPA: Marine Protected Areas

\section{Introduction}

Dark green coconut trees and loaded white sand embrace the beauty of the beaches of Kerala. Beaches of Kerala are extent along the 560-km Arabian Sea coastline. In the northern parts of Kerala, particularly in Kannur (Dharmadam beach is in Kannur district of Kerala), the outcrops ascend beyond the shore from the periphery of the beaches [1]. Kerala coasts hold cliffs, rocky outcrops, estuaries etc and mostly the beaches of Kerala are composed of sand (When compared to other sediment types, sandy sediments are widespread on beaches) with different grain size in conjunction with broken shells of molluscs. Some of the beaches in northern part of Kerala, mainly Dharmadam beach has been identified as crescent shaped pocket beaches (Beaches have crescent shape, mainly due to waves bending) [2].
Kerala coastal ecosystem is tremendously stressed due to high population density and land encroachment, reclamation for urbanization, farming and other various activities add to it. Ecology of Kerala beaches are rather unrepresented and unexplored, hence awareness of beach ecology will facilitate us in proper management and protection of coastal areas. The coastline of Kerala consists of open, sandy straight or barrier type beaches [3], sandy beaches being the largest coastal ecosystem on earth, covering $70 \%$ of all continental margins [4]. Beaches are of immense social and cultural significance to humans as prime recreational assets globally rather than any other kind of shoreline, beaches interrelate to people [5]. 
Sandy beaches mostly are short of biological structure, are physically organized environments, and prop up little insitu primary production; their food webs for that reason rely profoundly on imports from marine sources [4]. Present study investigated the anthropogenic invasions on different beaches and how they affected the community structure of those ecosystems. The assessment of benthic quality of the selected beaches was done with AMBI, which classifies macrofauna into five ecological groups based on the organism's stress sensitivity. Present study used AMBI index as ecological status marker by using macro invertebrates as indicators.

\section{Study Area}

Fort Cochin (Cochin, Kerala) and Dharmadam (Kannur, Kerala) beaches were preferred for the study, being stressed and pristine respectively and also with ample samples, these beaches were obvious choice; in addition these beaches are placed around $279 \mathrm{~km}$ apart. Fort Cochin beach (Sampling site 1) (Long $76^{0} 15^{\prime} 27^{\prime \prime} \mathrm{E}$, Lat. $90^{\circ} 57^{\prime} 58^{\prime \prime} \mathrm{N}$ ) is an open beach with continuous surf action, situated close to the bar mouth $(0.25 \mathrm{~km}$ south). It has an extensive berm with gently sloping nature and has fairly coarse sand.10-12m of beach from high tide mark (HTM) to low tide mark (LTM) will be exposed at low tide time. Dharmadam beach (Long. $75^{\circ} 27^{\prime} 23^{\prime \prime} \mathrm{E}$, Lat. $11^{0} 46^{\prime} 35^{\prime \prime} \mathrm{N}$ ) is also an exposed beach with mixed type of sediment composition; rocky and sandy (Figure 1). It is a long clean beach and the characteristics of the beach sand are fine sand with darker in color and adhering with scattered laterite rock formations. $15-30 \mathrm{~m}$ of beach from high (HTM) to low (LTM) will be exposed at low tide time. In each beach two stations were selected at a distance of $500 \mathrm{~m}$.

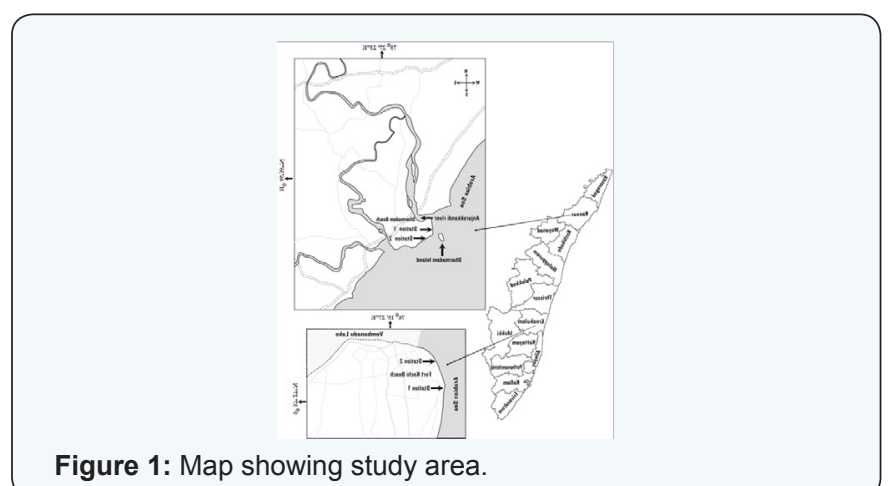

\section{Materials and methods}

Eighteen months of continuous monthly sampling and collections were done during low tide time and it was monitored from 2009 August to January 2011. Predicted tide tables were used for concluding low tide period. Long shore currents were measured by releasing a plastic bottle top into the water and determining the time for it to travel one meter. Three consecutive readings were taken [6]. Number of waves and Angle of approach of waves have been measured by visual observation and by using magnet respectively [7]. Quantitative sampling methods were used for the sampling process. Transect was taken and lined across the width of the beach, generally $10-30 \mathrm{~m}$ transect was taken at both the beaches. In Fort Cochin beach the exposed area of the beach at low tide time was $10-12 \mathrm{~m}$ and in Dharmadam it was $15-30 \mathrm{~m}$.

Along this transect, quadrate of $25 \times 25 \mathrm{~cm}\left(0.625 \mathrm{~m}^{2}\right)$ were placed at regular intervals by using stratified random sampling method. Four quadrates were placed along the transect in each station. Sediments up to $15 \mathrm{~cm}$ within the quadrate were collected and sieved through the $0.5 \mathrm{~mm}$ mesh sieve $(500 \mu)$. The organisms obtained after sieving were transferred to a plastic bottle and preserved in diluted 5\% buffered formalin with filtered sea water [8]. The fixed specimens were stained with $1 \%$ Rose Bengal [9] for further identification. The epifauna of the rocky areas of beaches were collected by hand picking and also by using chisels. For quantitative measurements, quadrates were placed on rocky surface and the organisms within the quadrates were collected and preserved. Visual observations of organisms like birds of the beaches were also done for getting the trophic status of those beaches.

Water quality parameters from both the beaches were analyzed, by collecting water samples. Twelve water quality parameters, most influential to residing macrofauna of the selected shorelines were analyzed for the study. Temperature of water samples was measured by using centigrade thermometer (range $=0-50^{\circ} \mathrm{C}+0.1^{\circ} \mathrm{C}$ ) and $\mathrm{pH}$ by Systronics $\mathrm{pH}$ meter (No.335, accuracy+ 0.01). Salinity, turbidity and TDS (Total Dissolved Solids) were measured with Systronics water analyzer (Model no.317) and conductivity was measured by using digital potentiometer (Model no.318). Carbon dioxide and nutrients were measured according to standard procedures from APHA [10] and dissolved oxygen by Winkler's Method [11]. Arrays of Statistical analysis were done for the better explanation of sample data and the software program PRIMER Vs. 6.0 was used for this [12].

Statistical analysis like Caswell neutral model and ANOSIM (Analysis of Similarity) analysis were done. Caswell neutral model (V statistics) is a comparison of Shannon diversity ( $\left.\mathrm{H}^{\prime}\right)$ with expected diversity conditional on the observed number of species $\mathrm{S}$ and individuals $\mathrm{N}$ under some model rules for the community, which are 'ecologically neutral'. $V$ (N.D.) is calculated by subtracting $\mathrm{E}\left[\mathrm{H}^{\prime}\right]$ from $\mathrm{H}^{\prime}$ and dividing by the standard error of $\mathrm{H}^{\prime}$. ANOSIM is used to measure the dissimilarity matrix rather than raw data $\mathrm{R}$ value ranges from -1 to +1 .

\section{Biotic indices}

AMBI (AZTI's Marine Biotic Index): To get the ecological quality status of (EcoQS) benthic environment, biotic indices like AMBI (AZTI's Marine Biotic Index) are crucial. AMBI [13,14] used different soft bottom macrofauna for benthic quality assessment and classified them into 5 groups. 
Group 1: Sensitive species, present only in uncontaminated condition.

Group 2: Organisms unresponsive to organic enrichment with low densities.

Group 3: Tolerant species may occur in normal conditions and proliferated when organic enrichment occurs.

Group 4: Second order opportunist species with small size.

Group 5: First order opportunist species.

According to Muxika et al. [14], biotic coefficient value of AMBI from 0 - 1.2 is classified as normal community, undisturbed site and high ecological status.

1.2-3.3: Unbalanced community, slightly disturbed site, Good ecological status.

3.3- 4.3: Transitional to pollution, moderately disturbed site, moderate ecological status

\section{3 - 5: Polluted community, poor status}

5 - 5.5: Transitional to heavy pollution, heavily disturbed site,

\section{5-6.0: Heavy polluted, bad status}

6.0 -7.0: Azoic, extremely disturbed.

AMBI was calculated by using the formula,

\section{Results}

\section{Morphology and Basic features}

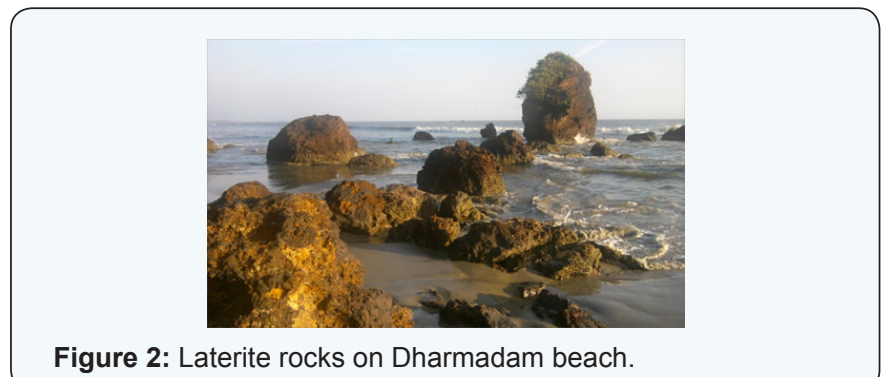

Figure 2: Laterite rocks on Dharmadam beach.

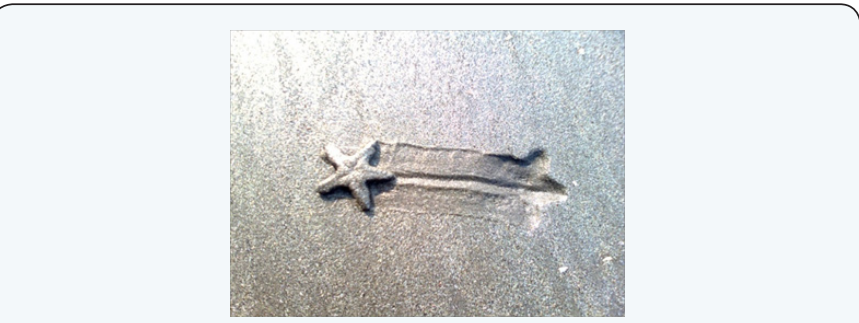

Figure 3: A moving sea star in the mid tide region of Dharmadm beach.This picture also shows the sparkling nature of the sediment during sunny days due to the presence of mica flakes in the sediments of Dharmadam beach.

Fort Cochin and Dharmadam beaches are sandy beaches, but certain sections of Dharmadam beach hold laterite rock formation on sandy crypt (Figure 2). Dharmadam laterite rocks are mainly composed of iron oxides and a laterite cliff can also be seen at Dharmadam rocky area. A green island located nearly $100 \mathrm{~m}$ distance of shore also holds lateritic rock formation, which highlights the geological importance of Dharmadam beach. This beach is flat and wide with fine sediments, mainly composed of mica. The mica flat flakes of the surface of the beach grains glint in light on sunny days (Figure 3). Mangroves and other vegetation are abundant on the rock cliff of the beach. Besides this, adjacent Dharmadam Island is also spotted as a mangrove area. Fort Cochin beach is also a sandy beach with coarser sand and it is highly attracted by tourists due to the existence of Chinese dip nets, a unique lure of Fort Cochin beach. Fort Cochin beach has an extensive berm with much steeper slope when compared to Dharmadam beach. During south-west monsoon (June-September) rigorous sea erosion takes place. Consequently sea walls and groins have constructed to avoid sea erosion. In October and December 2009, Fort Cochin beach exhibited accretion of sand and a wide portion of newly accreted sediment had been formed along with the beach. At Dharmadam beach also the erosion tendency of beach persists at south-west monsoon but comparatively the accretion tendency is lesser than that of Fort Cochin beach.

Wave action is more intense in Fort Cochin than Dharmadm beach and the frequency of waves is different in both beaches. Number of waves per minute at Fort Cochin was 9 (avg.) and time frequency was 5-8 seconds and in Dharmadam it was 6 no. /minute (avg.) and the time frequency was 6-9 seconds. Waves do not typically reach the beach perfectly parallel to the shoreline; they arrive slightly deviated to an angle to the beach. Angle of approach of waves at Fort Cochin was 100-1100 and at Dharmadam it was $90-110^{\circ}$. Coastal tidal ranges vary globally and it will be from near zero to over 11 meters. When the tidal range is lower than 2 meters it is classified as micromareal. Here at both the beaches maximum tidal amplitude was $1.3 \mathrm{~m}$, so it is classified under micro tidal region. The speed of Long shore current at Fort Cochin was $0.025-0.038 \mathrm{~m} / \mathrm{s}$ and in Dharmadam it was $0.023-0.034 \mathrm{~m} / \mathrm{s}$.

Ripple formation was a common feature in Dharmadam beach. According to Chakrabarti [15] energy levels of waves and currents of intertidal region exert strong control on ripple formation patterns. In Dharmadam ripple formation was observed in almost all the months during the sampling, however in Fort Cochin it was totally absent. The ripple observed was somewhat symmetrical and formed as a result of back and forth motion of wave action. The upper crest of the ripple was not so straight. Tidal channel is also a permanent feature in Dharmadam beach and it is important for the birds and marine larval forms. The channel observed to be deep in monsoon season due to high influx of water and shallow during pre and post-monsoon season. Laterite rock formation of Dharmadam beach also gives numerous micro habitats to the epifauna as it 
has lot of holes on rocks and small tide pools. The iron oxide rich laterite rocks are frail and change in shape and position was also observed seasonally during the study. Weathering of rocks may increase due to intense wave action of rocky areas.

Avian fauna were also observed from both the beaches and it was observed that eagles and crows were common in both the beaches and sea gulls and king fisher's were observed occasionally at Dharmadam beach. The honey comb like structures of sand, underneath the rocks were also another attraction of Dharmadam beach. These are made by sand castle worms and these sandy formations are very delicate. Sand castle worms are abundant in low tide region and they are exposed only in lowest low tides (Figure 4).

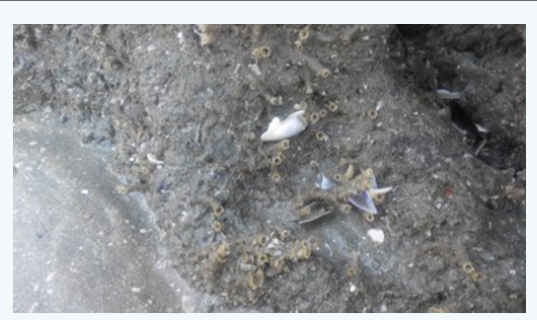

Figure 4: Sand castle worms (Phragmatopoma species in low tide zone of rocky beach area in Dharmadam beach).

\section{Intertidal macro fauna}

Faunal characteristics of both the beaches showed disparity in some groups and similarity in some. At Fort Cochin beach two stations were selected for the study at a distance of $500 \mathrm{~m}$. Twenty four species were identified from both the stations of Fort Cochin beach and dominant groups identified were amphipods (42\%) followed by polychaetes (28\%). In addition to these, bivalves (Donax sp.), polychaetes (Neries sp., Heteromastus sp., capitella capitata, mediomastus capensis, puliella armta, notomastus $s p$.), oligochaetes, mole crabs (Emerita sp, Emerita rathbunae), amphipods (Amphilochus picadurus, Paramicrodeutopus schmitti, Microdeutopus gryllotalpa, Gammaropsis sp, Gnathopleustes $s p$, Hyalella sp. Callopius carinatus), Ispopods (Spheromopsis $s p$.), mysids and tanaids, were also observed. The beach at Fort Cochin produced fewer species and the vertical distribution of organisms was not consistent throughout the sampling (Figures $5 \& 6)$.

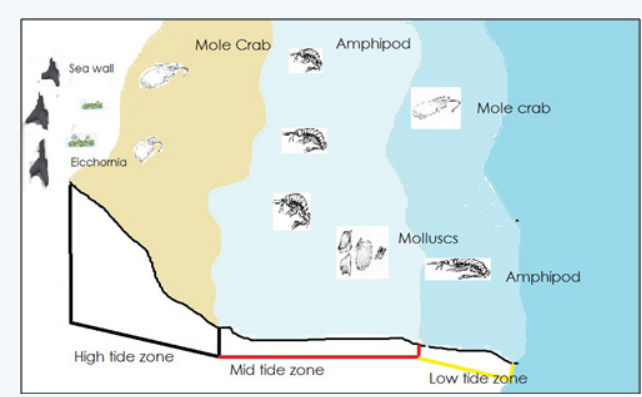

Figure 5: Zonation pattern of Fort Cochin beach (station 1).

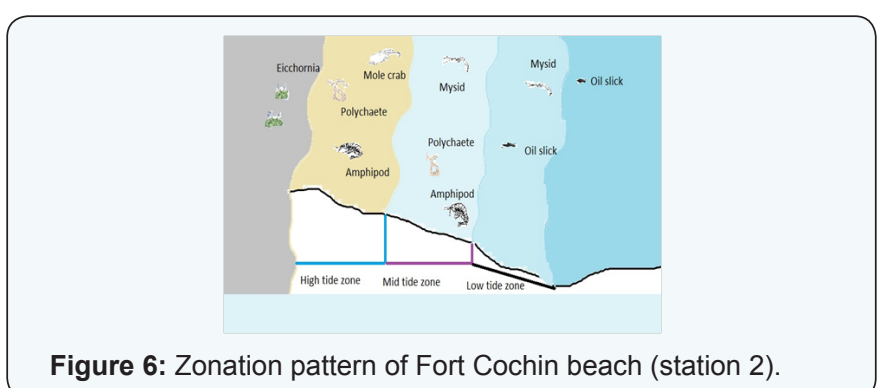

From the two stations observed in Dharmadam beach zone, about thirty four species of macro invertebrates were obtained. Among the identified samples, gastropods (Turbo sp., Nassarius sp., Trochus maculatus, Natica genuosa, Cymasium sp, Bufonaria sp., Turricula sp.), tanaids, and polychaetes (Scoleepis squamata, Glycera longipinnis sp., Paraonides sp, Glycera sp, Nereis sp. Neries willeyi, Prionospio cirrobranchiata, Prionospio ehlersi, Prionospio sp., Priospio sexoculata, Oweni ssp., Spio filcornis) formed the dominant organisms. The number of tanaids (43.4\%) was highest at station 1 when compared to other groups, whereas in station 2 , gastropods (45.54\%) were dominant. Shore crabs (Ocypode $s p$, juveniles of Ocypods, Dotilla sp.), hermit crabs (Diogene sp.), mole crabs (Emerita holthuissi, Emerita talpoida), bivalves (Donax sp., Perna viridis, Crassostrea madrasensis), amphipods (Pontocraytes altamarinus), isopods (Eurydice peraticis and Sphaeromopsis sp.), sea urchins (Psammechinus milaris), sea stars (Astropecten irregularis) were also observed as well. The distribution of organisms from HTM to LTM was almost consistent throughout the sampling (Figures 7 \& 8) and vertical distribution of organisms was prominent on rocks of Dharmadam beach. The epifauna residing there are mainly isopods (Ligia $s p$.), gastropods (Littorina $s p$, Patella $s p$.) etc. Bivalves observed were Perna viridis and Crassostrea madrasensis. Barnacles (Semibalanus balanoides) and sea anemones were also identified from the spot.

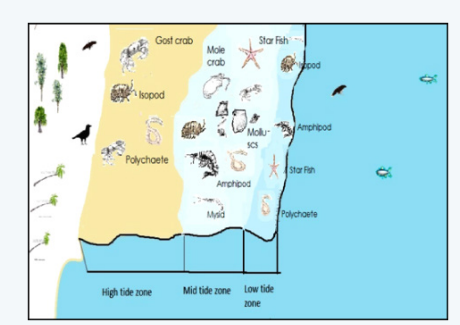

Figure 7: Zonation pattern of Dharmadam beach (station 1).

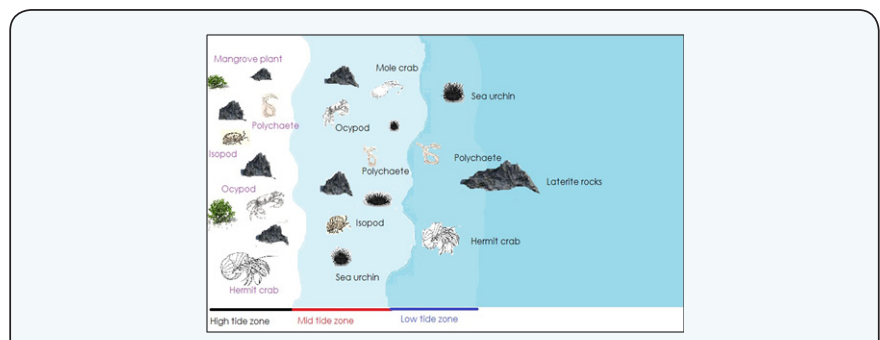

Figure 8: Zonation pattern of Dharmadam beach (station 2). 


\section{Zonation patterns}

\section{Beach vegetation}

Both the beaches have shore vegetation near to the shore line and Dharmadam beach embraces variety of flora when compared to Fort Cochin beach. Vegetation on the beach plays a significant role in beach stabilization, erosion and prevention. The major plants observed from the Dharmadam beach were coconut trees (Coccos nucifera), Pandanus sp, Casuarina sp, beach morning glory or rail road vine (Ipomoea pescaprae) (Figure 9), mangroves, almond tree (Badam) etc. A small forest of Casuarina $s p$. is also present in the shore line of the Dharmadam beach. At Fort Cochin the major plants observed were coconut trees (Coccos nucifera), May flower tree or gulmohar (Delonix regia), Jarul (Lagerstroemia speciosa), banyan tree (Ficus bengalensis), rail road vines (Ipomoea pescaprae) etc.

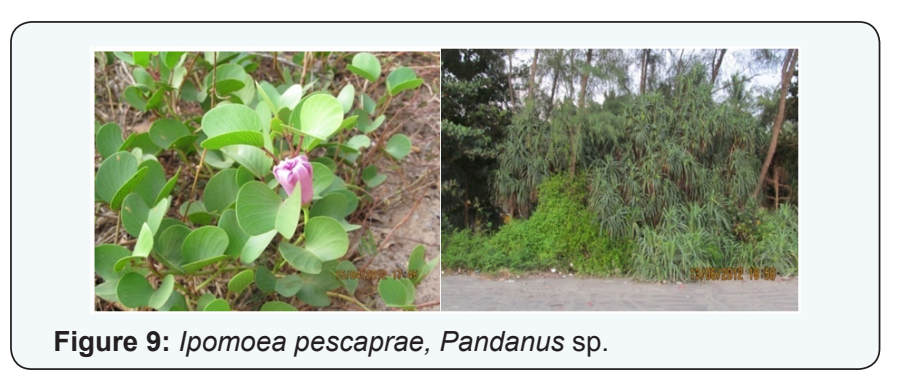

\section{Faunal Diversity}

In Fort Cochin beach (Station 1), seasonal diversity index showed highest diversity in post- monsoon season, 2009 (Postmonsoon 1) $\left(H^{\prime}=1.13\right)$ with high species richness $(d=1.3)$. Species evenness was observed high in post-monsoon season, 2010 (post-monsoon 2) (j'= 0.99) with lesser dominance of species $\left(\lambda^{\prime}=0.33\right)$. Lesser diversity was observed in monsoon season, 2010 (Monsoon 2) $\left(H^{\prime}=0.80\right)$ (Table 1).

Table 1: Seasonal values of diversity indices in station 1 of Fort Cochin beach during 2009-2011(d - Margalef's richness, j'- Pielou's Evenness, H'-Shannon Wiener Diversity, $\lambda^{\prime}$-Simpson's Dominance).

\begin{tabular}{|c|c|c|c|c|}
\hline & $\mathbf{d}$ & $\mathbf{j}^{\prime}$ & $\mathbf{H}^{\prime}($ loge $)$ & $\lambda^{\prime}$ \\
\hline Monsoon 1 & 1.0 & 0.57 & 0.92 & 0.55 \\
\hline Post-monsoon 1 & 1.3 & 0.63 & 1.13 & 0.46 \\
\hline Pre-monsoon 1 & 0.94 & 0.58 & 0.81 & 0.58 \\
\hline Monsoon 2 & 0.70 & 0.73 & 0.80 & 0.54 \\
\hline Post-monsoon 2 & 0.70 & 0.99 & 1.09 & 0.33 \\
\hline
\end{tabular}

In station 2 diversity index showed higher diversity with less species dominance in monsoon, 2009 (Monsoon 1) $\left(H^{\prime}=1.3, \lambda^{\prime}=\right.$ 0.26). Post-monsoon season, 2010 (Post-monsoon 2) showed lesser diversity when compared to other seasons $\left(H^{\prime}=0.79\right)$. High evenness was shown in monsoon season, $2009\left(j^{\prime}=0.98\right)$ and high richness was observed in post-monsoon season, 2009 (Post-monsoon 1) (d=0.923) (Table 2).
Table 2: Seasonal values of diversity indices in station 2 of Fort Cochin beach during 2009-2011.

\begin{tabular}{|c|c|c|c|c|}
\hline & $\mathbf{d}$ & $\mathbf{J}^{\prime}$ & $\mathbf{H}^{\prime}($ loge) & $\boldsymbol{\lambda}^{\prime}$ \\
\hline Monsoon 1 & 0.92 & 0.98 & 1.35 & 0.26 \\
\hline Post-monsoon 1 & 0.92 & 0.66 & 1.06 & 0.40 \\
\hline Pre-monsoon 1 & 0.54 & 0.88 & 0.97 & 0.41 \\
\hline Monsoon 2 & 0.85 & 0.61 & 0.85 & 0.53 \\
\hline Post-monsoon 2 & 0.62 & 0.72 & 0.79 & 0.50 \\
\hline
\end{tabular}

Seasonal diversity index showed higher diversity in Monsoon, 2009 (Monsoon 1) Dharmadam beach (station 1) $\left(H^{\prime}=1.58\right)$ with low dominance of species $\left(\lambda^{\prime}=0.20\right)$. Premonsoon season, 2010 showed higher species richness $(d=1.71)$ and higher species evenness was shown in monsoon season, 2009 (Monsoon 1) ( $\left.j^{\prime}=0.98\right)$. Higher dominance was observed in post-monsoon season, 2009 (Post-monsoon 1) $\left(\lambda^{\prime}=0.42\right)$ with uneven distribution $\left(j^{\prime}=0.64\right)$. A decreasing trend of diversity was observed from season to season (monsoon, 2009 to postmonsoon, 2010) (Table 3).

Table 3: Seasonal values of diversity indices in station 1 of Dharmadam beach during 2009-2011.

\begin{tabular}{|c|c|c|c|c|}
\hline & d & $\mathbf{J}^{\prime}$ & $\mathbf{H}^{\prime}($ loge) & $\lambda^{\prime}$ \\
\hline Monsoon 1 & 0.96 & 0.98 & 1.58 & 0.20 \\
\hline Post-monsoon 1 & 0.97 & 0.64 & 1.15 & 0.42 \\
\hline Pre-monsoon 1 & 1.71 & 0.65 & 1.44 & 0.35 \\
\hline Monsoon 2 & 1.12 & 0.79 & 1.27 & 0.33 \\
\hline Post-monsoon 2 & 1.05 & 0.77 & 1.07 & 0.41 \\
\hline
\end{tabular}

In station 2 diversity index showed higher diversity in post-monsoon season, 2009 (Post-monsoon 1) $\left(H^{\prime}=1.86\right)$ with lesser dominance $\left(\lambda^{\prime}=0.17\right)$. Species evenness was more in pre-monsoon season, $2010\left(j^{\prime}=0.92\right)$ with lesser richness of species $(d=0.97)$ and high species richness was observed in post-monsoon season, 2010 ( $d=1.59$ ). Monsoon, 2010 showed lesser diversity $\left(H^{\prime}=1.42\right)$ with comparatively even distribution of species $(\mathrm{d}=0.88)$ (Table 4$)$.

Table 4: Seasonal values of diversity indices in station 2 of Dharmadam beach during 2009-2011.

\begin{tabular}{|c|c|c|c|c|}
\hline & $\mathbf{d}$ & $\mathbf{J}^{\prime}$ & $\mathbf{H}^{\prime}$ (loge) & $\boldsymbol{\lambda}^{\prime}$ \\
\hline Monsoon 1 & 1.57 & 0.72 & 1.51 & 0.31 \\
\hline $\begin{array}{c}\text { Post- } \\
\text { monsoon 1 }\end{array}$ & 1.41 & 0.85 & 1.86 & 0.17 \\
\hline $\begin{array}{c}\text { Pre- } \\
\text { monsoon 1 }\end{array}$ & 0.97 & 0.92 & 1.65 & 0.21 \\
\hline Monsoon 2 & 1.12 & 0.88 & 1.42 & 0.26 \\
\hline $\begin{array}{c}\text { Post- } \\
\text { monsoon 2 }\end{array}$ & 1.59 & 0.82 & 1.47 & 0.27 \\
\hline
\end{tabular}

\section{Caswell (V-Statistics) (Caswell's neutral model)}

Caswell neutral model was applied to seasonal abundance data to compare the Shannon Wiener diversity $\left(\mathrm{H}^{\prime}\right)$ with the predicted diversity values $\left(\mathrm{E}\left[\mathrm{H}^{\prime}\right]\right)$ as proposed by Caswell in 
his neutral model, measures theoretical diversity for a sample of observed number of species (S) and individuals (N) under model assembly rules for the community, which are ecologically neutral [13]. In Fort Cochin (station 1), the V value was negative in monsoon, post-monsoon (2009) and pre-monsoon (2010) seasons $(-0.79,-0.66$ and -0.90 in monsoon, post and premonsoon season- respectively). The predicted diversity values were also higher than actual diversity values $\left(\mathrm{E}\left[\mathrm{H}^{\prime}\right]=1.1\right.$ and $\mathrm{H}^{\prime}=0.92$ in monsoon season, $\mathrm{E}\left[\mathrm{H}^{\prime}\right]=1.2$ and $\mathrm{H}^{\prime}=1.1$ in post monsoon season, $\mathrm{E}\left[\mathrm{H}^{\prime}\right]=0.99$ and $\mathrm{H}^{\prime}=0.81$ in pre-monsoon season), indicating lesser diversity values than 'neutrality'. The negative value of $\mathrm{V}$ implies excessive dominance of species Table 5: CASWELL diversity tables of total fauna (Seasonal) in station in monsoon and pre-monsoon season (Table 5), might be an indication of any disturbances to the assemblage during that time. In Fort Cochin (station 2) monsoon season (2010) showed negative $\mathrm{V}$ value $(-0.3)$ and higher predicted diversity (0.94) than actual diversity (0.85). Other seasons showed positive $\mathrm{V}$ value indicating greater diversity than 'neutrality' (Table 6). In Dharmadam beach (Station 1), pre monsoon season showed negative $\mathrm{V}$ value and higher predicted diversity $\left(\mathrm{E}\left[\mathrm{H}^{\prime}\right]=1.5\right)$, which might be due to excessive dominance of species (Table 7). In station 2, all seasons exhibited positive $V$ value, indicating greater diversity than neutrality (Table 8).

\begin{tabular}{|c|c|c|c|c|c|c|c|c|c|}
\hline Column1 & N & S & $\mathbf{H}^{\prime}$ & $\mathbf{E}\left[H^{\prime}\right]$ & $\mathbf{S D}\left[H^{\prime}\right]$ & V(N.D.) & F-ratio & DF1 & DF2 \\
\hline Monsoon 1 & 44 & 5 & 0.92 & 1.10 & 0.23 & -0.79 & 0.61 & 12.84 & 5.83 \\
\hline Post-monsoon 1 & 46 & 6 & 1.13 & 1.28 & 0.22 & -0.66 & 0.68 & 17.3 & 6.89 \\
\hline Pre-monsoon 1 & 24 & 4 & 0.81 & 0.99 & 0.20 & -0.90 & 0.55 & 12.4 & 4.85 \\
\hline Monsoon 2 & 17 & 3 & 0.80 & 0.78 & 0.18 & 0.128 & 1.11 & 8.95 & 3.65 \\
\hline Post-monsoon 2 & 17 & 3 & 1.09 & 0.78 & 0.18 & 1.70 & 1.26 & 8.95 & 3.65 \\
\hline
\end{tabular}

Table 6: CASWELL diversity tables of total fauna (Seasonal) in station 2 of Fort Cochin beach during 2009-2011.

\begin{tabular}{|c|c|c|c|c|c|c|c|c|c|}
\hline Column 1 & N & S & H' $^{\prime}$ & E[H'] & SD[H'] & V(N.D.) & F-ratio & DF1 & DF2 \\
\hline Monsoon 1 & 26 & 4 & 1.35 & 0.98 & 0.20 & 1.82 & 20.73 & 11.76 & 4.82 \\
\hline Post-monsoon 1 & 76 & 5 & 1.06 & 1.01 & 0.26 & 0.19 & 1.151 & 9.77 & 5.73 \\
\hline Pre-monsoon 1 & 38 & 3 & 0.97 & 0.67 & 0.23 & 1.30 & 4.89 & 5.29 & 3.38 \\
\hline Monsoon 2 & 33 & 4 & 0.85 & 0.94 & 0.22 & -0.38 & 0.76 & 10.08 & 4.74 \\
\hline Post-monsoon 2 & 24 & 3 & 0.79 & 0.72 & 0.20 & 0.30 & 1.30 & 6.96 & 3.51 \\
\hline
\end{tabular}

Table 7: CASWELL diversity tables of total fauna (Seasonal) in station 1 of Dharmadam beach during 2009-2011.

\begin{tabular}{|c|c|c|c|c|c|c|c|c|c|}
\hline Column1 & $\mathbf{N}$ & $\mathbf{S}$ & $\mathbf{H}^{\prime}$ & $\mathbf{E}\left[\mathbf{H}^{\prime}\right]$ & SD[H'] & V(N.D.) & F-ratio & DF1 & DF2 \\
\hline Monsoon 1 & 63 & 5 & 1.58 & 1.04 & 0.25 & 2.14 & 38.14 & 10.66 & 5.76 \\
\hline Post-monsoon 1 & 169 & 6 & 1.15 & 1.05 & 0.29 & 0.33 & 1.25 & 9.66 & 6.70 \\
\hline Pre-monsoon 1 & 106 & 9 & 1.44 & 1.53 & 0.24 & -0.35 & 0.83 & 22.49 & 9.71 \\
\hline Monsoon 2 & 35 & 5 & 1.27 & 1.14 & 0.21 & 0.58 & 1.52 & 14.72 & 5.89 \\
\hline Post-monsoon 2 & 17 & 4 & 1.07 & 1.06 & 0.17 & 0.05 & 1.036 & 16.42 & 5.013 \\
\hline
\end{tabular}

Table 8: CASWELL diversity tables of total fauna (Seasonal) in station 2 of Dharmadam beach during 2009-2011.

\begin{tabular}{|c|c|c|c|c|c|c|c|c|c|}
\hline Column1 & $\mathbf{N}$ & $\mathbf{S}$ & $\mathbf{H}^{\prime}$ & $\mathbf{E}\left[\mathbf{H}^{\prime}\right]$ & $\mathbf{S D}\left[\mathbf{H}^{\prime}\right]$ & $\mathbf{V}$ (N.D.) & F-ratio & DF1 & DF2 \\
\hline Monsoon 1 & 85 & 8 & 1.51 & 1.45 & 0.24 & 0.24 & 1.15 & 20.51 & 8.78 \\
\hline Post-monsoon 1 & 284 & 9 & 1.86 & 1.35 & 0.29 & 1.76 & 3.54 & 15.41 & 9.58 \\
\hline Pre-monsoon 1 & 169 & 6 & 1.65 & 1.05 & 0.29 & 2.06 & 8.66 & 9.66 & 6.70 \\
\hline Monsoon 2 & 35 & 5 & 1.42 & 1.14 & 0.21 & 1.29 & 3.16 & 14.72 & 5.89 \\
\hline Post-monsoon 2 & 23 & 6 & 1.47 & 1.43 & 0.16 & 0.27 & 1.18 & 28.53 & 7.12 \\
\hline
\end{tabular}

\section{Similarity of total groups with different abiotic factors using ANOSIM}

Twelve water quality parameters have been identified from the study area. Temperature, $\mathrm{pH}$, Salinity, carbon dioxide, dissolved oxygen, conductivity, TDS, turbidity, phosphate, silicate, nitrate and nitrite. Total faunal groups in Fort Cochin beach with dissolved oxygen illustrated $\mathrm{R}$ value as -0.059 and significance level was greater than 0.05 ( $p<81 \%$, p $>0.05$ ).
This near zero $\mathrm{R}$ value indicates no significant segregation of samples with DO variation. Gastropods showed $0.053 \mathrm{R}$ value and significance level greater than $0.05(\mathrm{p}<14 \%$, $\mathrm{p}>0.05)$ with salinity in Dharmadam beach. Amphipods showed $-0.035 \mathrm{R}$ value and significance level was greater $(p<88 \%$, $p>0.05)$ with salinity in Fort Cochin beach. Total faunal groups in Dharmadam beach showed global $\mathrm{R}$ value as 0.03 and significance level greater than $0.05(\mathrm{p}<17 \%, \mathrm{p}>0.05)$ with dissolved oxygen. 
Polychaetes in Dharmadam beach showed $-0.024 \mathrm{R}$ value and significance level was $\mathrm{p}<71 \%$, $\mathrm{p}>0.05$ with temperature and in Fort Cochin polychaetes showed $-0.072 \mathrm{R}$ value and significance level greater than $0.05(\mathrm{p}<93 \%, \mathrm{p}>0.05)$ with temperature. The all above mentioned analyses were shown near zero $R$ value and consequently no significant segregation with abiotic factors was observed.

\section{Similarity of dominant macrofauna with tide height using ANOSIM}

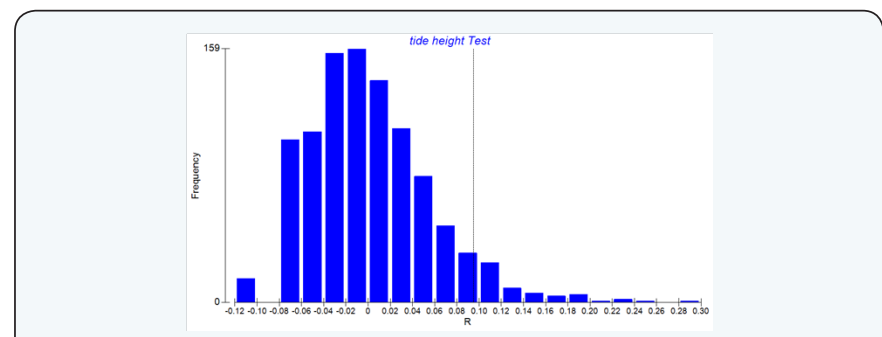

Figure 10: Histogram showing ANOSIM similarities with gastropod species and tidal height in Dharmadam beach during 2009-2011 (Global $R=0.09, p>0.05$ ).

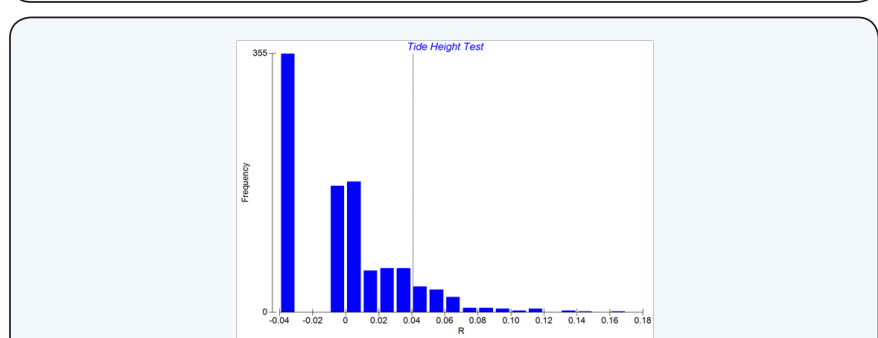

Figure 11: Histogram showing ANOSIM similarities with amphipod species and tidal height in Fort Cochin beach during 2009-2011 (Global $R=0.04 p>0.05$ ).

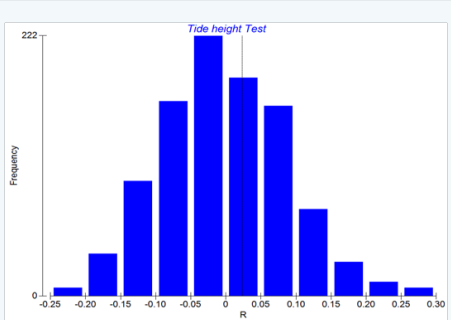

Figure 12: Histogram showing ANOSIM similarities with polychaete species and tidal height in Fort Cochin beach during 2009-2011 (Global $R=0.02 p>0.05$ ).

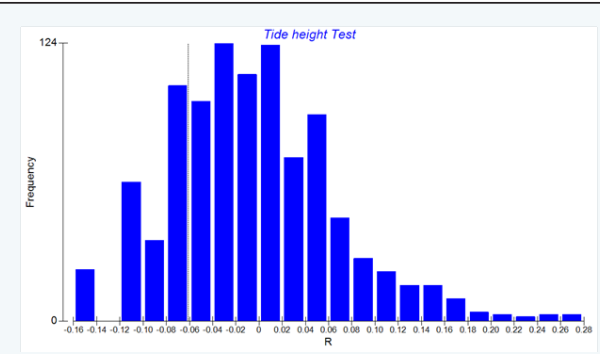

Figure 13: Histogram showing ANOSIM similarities with polychaete species and tidal height in Dharmadam beach during 2009-2011 (Global $R=-0.067 p>0.05$ ).
Similarity of polychaetes, amphipods and gastropods were observed with tide height to discern their significance level with different tidal height. Gastropods from Dharmadam beach showed no significant segregation with tide height $(R=0.09$, $p>0.05$ ) (Figure 10). Amphipods from Fort Cochin beach also demonstrated that there was no significant segregation with tidal height $(\mathrm{R}=0.04, \mathrm{p}>0.05)$ as per ANOSIM analysis (Figure 11). Polychaetes from both the beaches were also observed and in both Fort Cochin and Dharmadam beaches the polychaetes illustrated no significant segregation with tidal height $(R=0.02$, $p>0.05$ and $R=-0.067, p>0.05$ ) (Figures $12 \& 13$ ). All the $R$ values observed were close to zero, as per Clarke et al. [13], $\mathrm{R}$ values close to zero implying no segregation between samples. The significance level observed were also higher than alpha significance value $(0.05)$, indicating no significance between samples.

\section{AMBI (AZTI's Marine Biotic Index)}

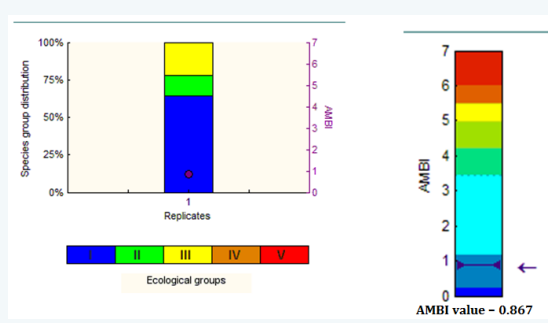

Figure 14: $A M B I$ value and relative abundance of ecological groups in station 1 of Fort Cochin beach

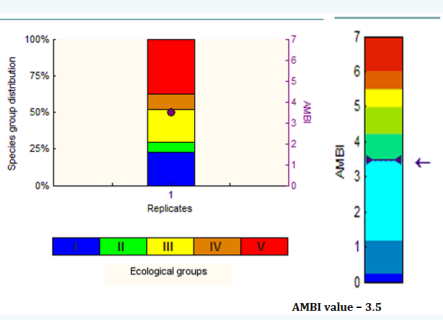

Figure 15: $\mathrm{AMBI}$ value and relative abundance of ecological groups in station 2 of Fort Cochin beach.

For the assessment of benthic quality of the selected beaches AMBI was calculated and according to AMBI classification macrofauna were classified into five ecological groups based on the organism's sensitivity to stress. In Fort Cochin beach (station 1), AMBI index explained that the observed macrofauna were coming under group 1. Group 1 species are very sensitive to organic enrichment and present only in non polluted condition. The AMBI index value was 0.867 , according to the classification the value in between $0-1.2$ is classified as an unpolluted condition with high ecological status. According to AMBI analysis Fort Cochin beach (station 1) confirmed as unpolluted beach with sensitive organism (Figure 14). In station 2 the AMBI index showed dominance of group 3 organisms, these are tolerant species and may present in normal conditions and if organic enrichment occurs, the population increases. The AMBI 
value was 3.5 and the value 3.2 - 5 is considered as moderately polluted condition with moderate ecological status. The benthic community health is transitional to pollution in station 2 according to AMBI classification (Figure 15).

In Dharmadam beach (station 1) AMBI index explained dominance of group 2 organisms. According to the classification the group 2 organisms are species unresponsive to enrichment and variation is less with time. The AMBI value was 1.491 , it is coming under slightly disturbed nature with good ecological status according to the classification. An unbalanced community health was observed in station 1 (Figure 16) and the value from 1.2-3.2 is considered as slightly polluted. In station 2, organisms were coming under group 2 and AMBI value was 1.545 , subsequently it was classified under slightly disturbed with good ecological status (Figure 17).

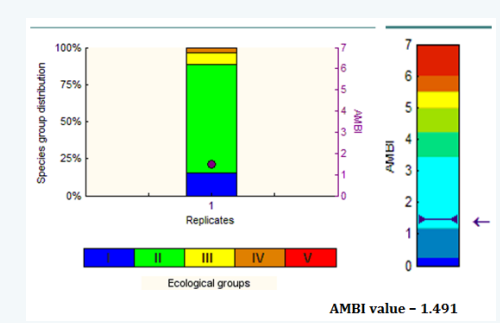

Figure 16: $A M B I$ value and relative abundance of ecological groups in station 1 of Dharmadam beach.

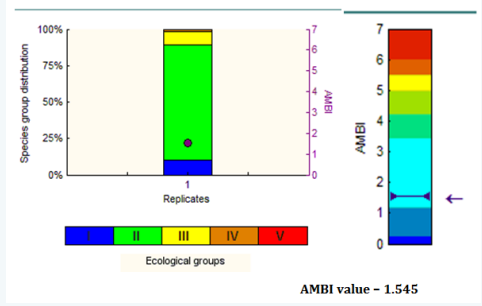

Figure 17: $\mathrm{AMBI}$ value and relative abundance of ecological groups in station 2 of Dharmadam beach.

\section{Human impacts}

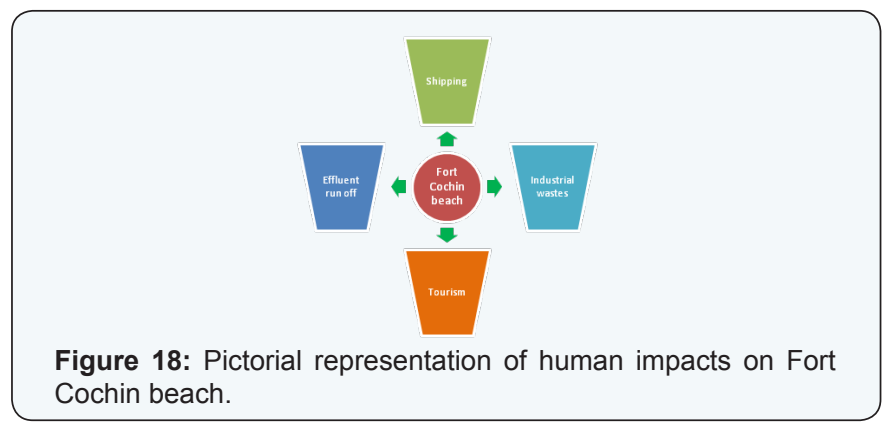

Fort Cochin beach is known for its beauty; nevertheless the human interactions are more prominent in this beach. There are many sources of pollution like industrial effluents, fishing, run off from near areas, shipping (oil slicks) and tourism etc. In addition to this, dead and decaying Eichornia washed towards the beach also creates disturbances to the intertidal organisms (Figure 18). Dharmadam beach is pristine natured with fishing being the only major human activity, tourism is in early stage as the Dharmadam Island nearby beach and rocky outcrops of the beach fascinate tourists (Figure 19). Fishing operations are mainly by traditional boats and nets.

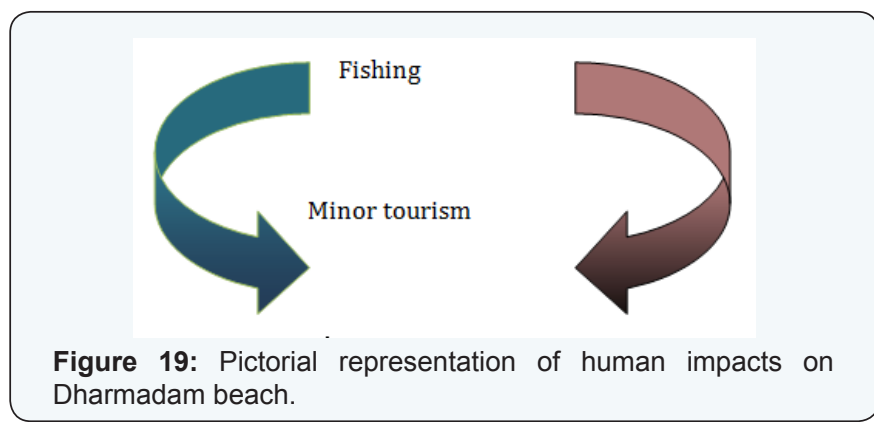

\section{Discussion}

In spite of the fact that the Fort Cochin and Dharmadam shorelines are sandy in nature however in morphology and in faunal composition they are indicating diverse appearance. Fundamentally, shore morphology is a component of waves and sediment [16,17]. A range of additional processes, such as tide and wind, additionally impact the shore morphodynamics. Morphological contrasts are more prominent in the chose shorelines; based on sediment, Fort Cochin holds coarse sand whereas Dharmadam shoreline embraces fine sand. The morphology of a beach results from the interactions between the available sediment and the energy of the waves impinging on the shoreline $[16,17]$. The gentle steep nature of Fort Cochin beach and flat nature of Dharmadam beach show the intensity of waves on those beaches.

Rather high intense nature of waves of Fort Cochin than Dharmadam endorses the profile difference of both the beaches. Fine sediments absorb a little water but coarse sediments absorb more water that flows up and down the beach [18]. Most of the beaches in Kerala show evidence of erosion and deposition owing to waves of monsoon and fair whether seasons. During October to March all the beaches show accreting tendency under the influence of north westerly waves [4]. Fort Cochin beach is more prone to accretion and erosion than Dharmadam beach due to intense wave action and deposition of sand in the banks of Cochin estuary by dredging activities. Rocky outcrops of Dharmadam seashore increase the geological importance of that field and the laterite rocks found there are primary laterites, weathering product of basalt. The green island placed within the close shore at a hundred meter in the direction of west of Dharmadam is fashioned by highly eroded main laterites [1].

These iron oxide rich rocks are domicile of exclusive organism; it has acquired plenty of suitable habitats for organisms to survive than fort Cochin beach. Mangroves are also observed 
from Cochin estuary and Dharmadam [19], Dharmadam beach rock cliff is full of mangrove vegetation. As a consequence the ecological value of seashore raises as it's the best coastal habitats on this planet. The presence of mangroves in the rock cliffs of the seashore suggests the healthy atmosphere of Dharmadam beach. The island close to the Dharmadam beach additionally keeps bunch of vegetation and migratory birds. Sandy shores are highly dynamic in nature, Macrobenthic communities match well with the physical classification of sandy beaches, and the combined effect of wave energy, sand particle size and beach slope was once proposed as these are predominant factors influencing the macrofauna assemblage in intertidal ecosystem [20].

Vegetation of both the shores is showing disparity in their composition, it can be noticed easily as herbs and shrubs are further unique in Dharmadam beach, even as Fort Cochin has obtained lot of bushes. In most ecosystems, community structure appears as an outcome of the complex interaction among biotic and environmental variables [21]. The Shannon Wiener diversity index of Dharmadam beach showed that the beach system supports high abundance of two or three species which has led to less species richness as well as low species evenness. Species richness and diversity were comparatively higher in Dharmadam beach than Fort Cochin beach in seasonal observation. Taheri et al. [22] observed low diversity of macrofauna in monsoon season in Oman Gulf, but the present study observed high diversity in station 1 of Dharmadam and station 2 of Fort Cochin beach in monsoon season (2009).

One or a few species dominating a community shows low evenness while those communities that have more even distribution will have high evenness. The low species evenness observed in both the beaches corroborates the statement, indicating low ecosystem health as high evenness of species is an indication of healthy ecosystem. Nevertheless species evenness is not able to be held liable for the system health, the diversity also taking principal position. The distribution of organisms was not even in seasonal observations in both the beaches, indicating less diversity of species. The evenness component varied in compliance with $\mathrm{H}^{\prime}$. Communities with lower number of organisms that are dominated by one or a few species are least diverse. Some studies revealed that sandy beach ecosystems wherein species evenness and diversity are influenced by the population dynamics of numerically abundant species $[23,24]$. The study upholds this statement, at Fort Cochin beach among polychaetes, Capitella capitata was found to be abundant in station 2, where species evenness and diversity were observed to be low.

AMBI $[14,15]$ was performed to know the community disturbance and ecological status of the system. In Fort Cochin beach (Station 1) AMBI calculation illustrated undisturbed condition and moderate polluted condition in station 2 . Polychaetes were observed to be absent in Fort Cochin beach
(Station 1) except Arenicola, however Eichornia wrack was persistent throughout the sampling in Fort Cochin beach (station 1). From the above findings it may be assumed that the species present in station 1 have the capacity to self adapt with the stress condition. In Fort Cochin beach (station 2) opportunistic polychaete species were copious and the circumstance agrees with the findings of biotic index. In Dharmadam beach high and good ecological status were observed in AMBI, however the community from Dharmadam beach was observed to be slightly disturbed when AMBI was performed.

\section{Conclusion}

The presence of opportunistic species like Scolelepis and Prionospio species in Dharmadam beach could be connected to the AMBI results. From this it could be assumed that the pristine nature of Dhramadam beach could be altered in future due to human activities and the accumulation of opportunistic polychaetes may be an indication to that. Based on the above findings, it is clearly observed that the Fort Cochin beach is under peril due to anthropogenic effects and the proliferation of $r$ selected species (opportunistic) depicts the above fact. Elimination of $\mathrm{k}$ selected (species found in undisturbed conditions) species in Fort Cochin beach (Station 2) stating the notable effects of human activities in station 2. If the activities sustain constantly, it will lead to the ecosystem damage in near future.

Although the Dharmadam beach is in a good ecological status, the slightly disturbed community there giving an alarming fact that the proliferation of opportunistic species have started out and it is far pointing out the disturbances over there. Community disturbances may not be completely of anthropogenic stresses; however it may be due to changes in sediment structure, physical factors or food resources and anthropogenic disturbances also affect the water quality and organisms of that area. Studies have shown that anthropogenic activities may affect the animal physiology like growth rate, recruitment and mortality $[25,26]$. This study emphasizes the fact that these beaches are vulnerable to rigorous human activities. Most of the exposed beaches in south-west coast of India have prone to anthropogenic activities, like fishing, tourisms, industries and shipping industries.

These activities slowly transform the biotic communities of the beach ecosystem, which affects the food web and survival capacity of other faunal communities surviving there. Beaches are not only for recreational purpose but also it has a prominent role in coastal health. Misuse of beaches will lead to coastal ecosystem damage and the sustainability of coastal ecosystems is imperative as it influences the climatic changes and coastal life. Coastal zones restrain assorted and fruitful habitats imperative for anthropogenic actions and survival. Management of beaches and protection of their unique biodiversity necessitates intercession. In addition to direct anthropogenic impacts on beaches, global climate change also has various consequences for 
the intertidal ecosystem. Thus, management and conservation of the unique ecological features and processes of beaches have become critical and an imperative concern.

Coastal zone regulation act (2011) of Ministry of Environment and Forests, Govt. of India, restricts all developmental activities and waste disposal within $500 \mathrm{~m}$ of high tide zone of the intertidal region that comes under CRZ 1, the most ecologically sensitive zone. However, gross violation has been observed in Fort Cochin beach; probably in the near future there is a potential threat from intense human interventions in that beach and adjoining areas. Therefore based on the study, the following recommendations are put forth for effective management of the degrading littoral region of the Fort Cochin beach.

a) The Fort Cochin beach and adjoining areas are severely impacted, so it is proposed to have a "holiday period" to regulate the various increasing human activities (Fishing, mining and industrial) so that the ecosystem rejuvenates to its pristine condition.

b) The general awareness and ecological importance of the intertidal zones are to be given more thrust along with the concept of protection and conservation of our marine ecosystems.

c) Necessary modifications need to be implemented by the regulatory bodies to include the littoral zones and other coastal zones under the Marine Protected Areas (MPA) in category 1 for overall protection and conservation of the region.

\section{Acknowledgement}

Authors are thankful to the Head, Department of Marine Biology, Microbiology and Biochemistry, Cochin University of Science and Technology for providing the necessary facilities.

\section{References}

1. Avinash Kumar, Seralathan P, Jayappa KS (2009) Distribution of coastal cliffs in Kerala, India: their mechanisms of failure and related human engineering response. Environ Geol 58(4): 815-832.

2. Carl H Hobbs (2012) The Beach Book. Columbia university press, pp.192.

3. Kumudranjan Naskar, Rathindranath Mandal (1999) Ecology and Biodiversity of Indian Mangroves: Morpho-anatomy of mangroves. Vol 2, Daya publishers.

4. Jayappa KS, Vijaya Kumar GT, Avinash K (2009) Evolution of coastal landforms, Southern Karnataka: a remote sensing approach. Coastal environments: problems and perspectives. IK International Pvt. Ltd, New Delhi, pp. 79.

5. McLachlan A, Brown AC (2007) Ecology of sandy shores. Academic press, pp. 392.

6. Schlacher TA, Dugan J, Schoeman DS, Lastra M, Jones A, et.al. (2007) Sandy beaches at the brink. Diversity and Distributions 13(5): 556-560.
7. Giavolaa P, Tabordab R, Ferreiraa O, Alveirinho Diasa J (1996) Longshore Sand Transport: A Comparison between Field Observations and Predictions of Numerical Models and Implications for Coastal Erosion Studies. Partnership in Coastal Zone Management, Samara Publishing Limited, Cardigan, pp. 185-193.

8. Gillian Cambers, Fathimath Ghina (2005) Introduction to sand watch, an educational tool for sustainable development. UNESCO, France.

9. Eleftheriou A, McIntyre AD (2005) Methods for the study of marine benthos. Blackwell Science.

10. Pfannkuche O, Thiel H (1988) Sample processing. In: Higgins RP et al., (Ed.), Introduction to the study of meiofauna, Smithsonian Institution press, London.

11. Eaton AD (2005) Standard methods for the examination of water and waste water. ( $21^{\text {st }}$ edn), APHA, Washington, USA, pp. 1368.

12.12.Grasshoff K, Manfred EM, Kremling K, Almgren T (1983) Methods of seawater analysis. Verlag Chemie: 419.

13. Clarke KR, Gorley RN (2006), PRIMER V6: User Manual-Tutorial, PRIMER-E, Plymouth, pp. 189.

14. Borja A, Franco J, Pérez V (2000) A marine biotic index to establish the ecological quality of soft bottom benthos within European estuarine and coastal environments. Marine Pollution Bulletin 40(12): 11001114.

15. Muxika I., Borja A. and Bonne W (2005) The suitability of the marine biotic index (AMBI) to new impact sources along European coasts. Ecological Indicators 5(1): 19-31.

16. Chakrabarti A (2005) Sedimentary structures of tidal flats: A journey from coast inner estuarine region of eastern India. Journal of Earth system science 114(3): 353-368.

17. Brown, AC, McLachlan (1990), Ecology of Sandy Shores. Amsterdam, the Netherlands, Elsevier, pp. 392.

18. Short, AD (1999) Handbook of beach and shore face morphodynamics, Chichester, John Wiley \& Sons, pp. 379.

19. Pilkey OH, Rice TM, Neal WJ (2004) How to Read a North Carolina Beach. University of North Carolina Press, Chapel Hill, NC, pp. 162.

20. Jaramillo E, McLachlan A, Coetzee P (1993) Intertidal zonation patterns of macrofauna over a range of exposed sandy beaches in south central Chile. Marine Ecology Progress Series 101: 105-118.

21. Sivadas SK, Ingole B, Ganesan P, Sautya S, Nanajkar M (2012) Role of environment heterogeneity in structuring the macrobenthic community in a tropical sandy beach, west coast of India. Oceanogr 68(2): 295-305.

22. Taheri Mehrshad, Yazdani Foshtomi Maryam, Bagheri Hossein (2010) Community Structure and Biodiversity of Intertidal Sandy Beach Macrofauna in Chabahar Bay, Northeast of Oman Gulf, IR Iran. Journal of the Persian Gulf 1(1): 17-25.

23. Holland AF, Polgar TT (1976) Seasonal changes in the structure of an intertidal community. Mar Biol 37(4): 341-348.

24. Dexter DM (1984) Temporal and spatial variability in the community structure of the fauna of four sandy beaches in south-east New South Wales. Australian Journal of Marine and Freshwater Research 35: 663-72.

25. Tablado A, Lopez Gappa JJ, Magaldi NH (1994) Growth of the pulmonate limpet Siphonaria lesson (Blainville) in a rocky intertidal area affected by sewage pollution. J Exp Mar Biol Ecol 175(2): 211-226.

26. Johnston EL, Keough MJ (2002) Direct and indirect effects of repeated pollution events on marine hard-substrate assemblages. Ecol Appl 12(4): 1212-1228. 
Your next submission with JuniperPublishers will reach you the below assets

- Quality Editorial service

- Swift Peer Review

- Reprints availability

- E-prints Service

- Manuscript Podcast for convenient understanding

- Global attainment for your research

- Manuscript accessibility in different formats ( Pdf, E-pub, Full Text, Audio)

- Unceasing customer service

Track the below URL for one-step submission http://juniperpublishers.com/online-submission.php 